\title{
Review \\ Extraction and Quantification of Chlorophylls, Carotenoids, Phenolic Compounds, and Vitamins from Halophyte Biomasses
}

\author{
Laura S. S. Hulkko*D, Tanmay Chaturvedi and Mette Hedegaard Thomsen
}

Citation: Hulkko, L.S.S.; Chaturvedi, T.; Thomsen, M.H. Extraction and Quantification of Chlorophylls, Carotenoids, Phenolic Compounds, and Vitamins from Halophyte Biomasses. Appl. Sci. 2022, 12, 840. https://doi.org/10.3390/app12020840

Academic Editor: Catarina Guerreiro Pereira

Received: 3 December 2021

Accepted: 12 January 2022

Published: 14 January 2022

Publisher's Note: MDPI stays neutral with regard to jurisdictional claims in published maps and institutional affiliations.

Copyright: (C) 2022 by the authors. Licensee MDPI, Basel, Switzerland. This article is an open access article distributed under the terms and conditions of the Creative Commons Attribution (CC BY) license (https:// creativecommons.org/licenses/by/ $4.0 /)$.
AAU Energy, Aalborg University, Niels Bohrs Vej 8, 6700 Esbjerg, Denmark; tac@energy.aau.dk (T.C.); mht@energy.aau.dk (M.H.T.)

* Correspondence: 1ssh@energy.aau.dk

\begin{abstract}
Halophytes are salt-tolerant plants, and they have been utilised as healthy, nutritious vegetables and medicinal herbs. Various studies have shown halophytes to be rich in health-beneficial compounds with antioxidant activity, anti-inflammatory and antimicrobial effects, and cytotoxic properties. Despite their potential, these plants are still underutilised in agriculture and industrial applications. This review includes the state-of-the-art literature concerning the contents of proanthocyanidins (also known as condensed tannins), total phenolic compounds, photosynthetic pigments (chlorophyll and carotenoids), and vitamins in various halophyte biomasses. Various extraction and analytical methods are also considered. The study shows that various species have exhibited potential for use not only as novel food products but also in the production of nutraceuticals and as ingredients for cosmetics and pharmaceuticals.
\end{abstract}

Keywords: halophytes; bioactive molecules; saline cultivation; pigments; phenolics

\section{Introduction}

According to the European Innovation Partnership for Agricultural Productivity and Sustainability [1], soil salinisation is a significant threat to soils at a global scale, causing agricultural land degradation through natural causes or poor land and water management. As most conventional crops are salt-sensitive glycophytes, the increased salt concentration in cultivation soil causes nutritional imbalances and toxicity in plants, inhibiting their growth and making the soil unsuitable for traditional farming [1]. Loss of arable land affects the economic situation of people who depend on agricultural activities and creates a threat to the world's food security.

Halophytes are salt-tolerant plants adapted to thrive in saline habitats, such as seashores, marshlands, and saline deserts worldwide. Humans have used halophytes for centuries, primarily in medicinal practices, due to their high levels of bioactive compounds [2-4]. Nowadays, fresh shoots of halophytes are sold as gourmet vegetables [5,6]. Cultivation and commercialisation of these naturally salt-loving plants are seen as one of the critical implementations to help the remediation of saline areas and adapt to the changes in soil quality [1].

Vegetables and fruits are typically rich in health-beneficial bioactive compounds, such as phenolics and carotenoids [7,8]. However, these compounds can also be found in high concentrations in botanical extracts obtained from some agricultural and food processing waste, as mentioned in the review by Rauf et al. [7]. Halophytes are likely to produce high levels of these protective compounds due to their adaptation to extreme environmental conditions $[9,10]$. Besides healthy food, these plants could provide a novel feedstock for bio-functional feed, nutraceuticals, and the pharmaceutical industry [2,11-13]. For example, Lopes et al. [3] studied halophytes from saline habitats of southern Portugal and suggested various species that can potentially be utilised in cosmetic ingredients. These valuable bioactive compounds can also serve as value-added products that can be obtained from 
a halophyte-based biorefinery. For some succulent halophytes, such as Salicornia species, the food production period is relatively short, as the shrubs become more woody as they mature, making them unpleasant to eat. Due to high salt concentrations accumulated in the plant tissues, halophytes can be directly used as animal feed only when blended with other feed sources [14,15]. Therefore, these partly lignified plants are often considered agricultural waste. However, they could be used to extract phytochemicals as a part of a multi-product biorefinery. This concept is visualised in Figure 1. This would provide a value-added product stream for a biorefinery, whereasresidual extractive-free fibres could be utilised in bioenergy production, or in the production of other lignocellulose-derived products, such as bulk chemicals. Halophyte biomass has previously been tested for bioethanol and biogas production [16-18]. Production of botanical extracts can also be beneficial considering the pretreatment of lignocellulosic fibres, as it makes the fibres less recalcitrant, and lowers the severity of the pretreatment conditions that are needed $[16,19]$. Extraction with water would also remove salts which could otherwise cause issues during the processing [20]. In terms of other major compounds, since halophytes have exhibited interesting nutritional profiles [21-23], protein production has also been studied [24,25]. Despite their potential, halophytes are still underutilised both in agricultural and industrial applications $[3,12,23]$.

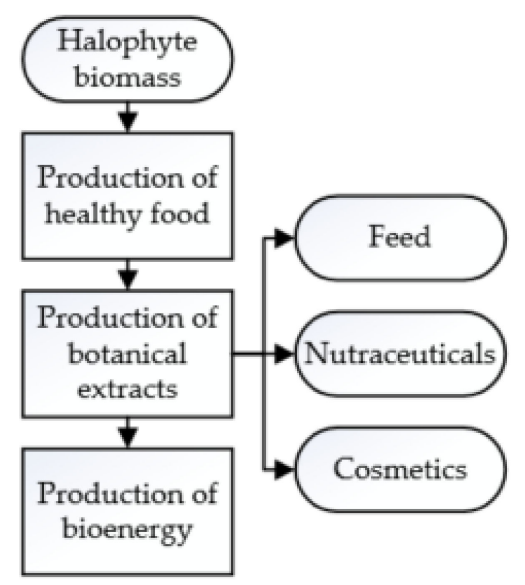

Figure 1. Simplified process chart of halophyte-based biorefinery.

\section{Methods}

This study reviews the existing literature reporting the phenolic compounds, pigments, and vitamins in halophyte biomass and provides information about the potential of these plants in multi-product biorefinery applications. Several scientific databases were used to retrieve articles, including those of Elsevier, Taylor \& Francis, Springer, and MDPI, but other peer-reviewed articles and some book chapters were also considered. Only articles written in English were considered, and the review focused on studies published in and after the year 2010. However, a few papers from 2008 and 2009 were also included. The review was performed to investigate the amount of the following compounds reported for botanical extracts from the biomass of edible halophytes:

- Proanthocyanidins (condensed tannins);

- Phenolic compounds (total phenols);

- Chlorophyll;

- Carotenoids;

- Vitamins.

The main keywords used in the search were: halophytes, phytochemicals, bioactive compounds, proanthocyanidin, condensed tannin, pigments, chlorophyll, carotenoid, and vitamins. Some of the reviewed studies compared the composition of different biomass batches of same species, or extraction methods. From these studies, the data from the 
sample with the highest concentration of the compound of interest was presented in the results. This review also briefly summarises the extraction methods and analytical procedures used to obtain, quantify, and identify the bioactive compounds. The strength of the solvent was also noted whenever it was specified in the original study.

\section{Proanthocyanidins}

Proanthocyanidins (also known as condensed tannins) are pigmented polymerised polyphenolic compounds that contribute to the antioxidant action and cardiovascular disease-preventing properties of botanical extracts, and these medicinal properties make them interesting for the pharmaceutical industry [26-28]. Rauf et al. [7] reviewed the reported health benefits linked to proanthocyanidins, and found that besides antioxidant and cardiovascular protective functions, condensed tannins have cancer-preventing, neuroprotective, and antimicrobial properties. In nature, proanthocyanidins are present in the flowers, leaves, fruits, nuts, seeds, and bark of various plants, protecting them from stress caused by environmental conditions or other living organisms, such as insects, parasitic nematodes, or diseases. More than a thousand derivatives of condensed tannins have been identified, and they have recently attracted increased interest due to their influence on various biological processes [29]. Plants rich in proanthocyanidins have also been used as herbal medicines for mild skin and oral mucosa inflammation and digestion issues [29].

The total amount of condensed tannins is typically determined from a methanol or acetone extract as an amount of catechin equivalent (CE) in the dry weight (DW) of the extract. The most common method for determining total condensed tannins is an applied vanillin assay method developed by Sun et al. [30], which is based on the reaction between catechin or proanthocyanidins and vanillin in methanol solution. However, a colourimetric method using 4-dimethylaminocinnamaldehyde hydrochloric acid (DMACA$\mathrm{HCl}$ ), developed by Li et al. [10], is said to have higher sensitivity and specificity compared to a vanillin assay.

Chekroun-Bechlaghem et al. [31] studied the extraction of polyphenolic compounds from halophyte biomasses using different solvents and found the concentration of condensed tannins was highest in aqueous fractions or methanol and acetone soluble fractions. As seen from Table 1, the level of proanthocyanidins in halophyte biomasses varies substantially between different species, even those within the same genus. For example, the concentration of proanthocyanidins in Mesembryanthemum species varies between $2.01 \pm 0.04 \mathrm{mgCE} / \mathrm{gDM}$ [32] and $20.3 \pm 0.98 \mathrm{mgCE} / \mathrm{gDM}$ [33], and in Suaeda species between $1.21 \pm 0.05 \mathrm{mgCE} / \mathrm{gDM}$ [32] and $15.76 \pm 1.43 \mathrm{mgCE} / \mathrm{g}$ [34]. The highest concentration of proanthocyanidins $(118.43 \pm 11.79 \mathrm{mgCE} / \mathrm{gDM})$, measured from water extract, was found from Tamarix africana [31]. For comparison, $17.28 \pm 1.95 \mathrm{mgCE} / \mathrm{gDM}$ of proanthocyanidins were found from Tamarix gallica [35] species within the same genus.

Table 1. The total amount of proanthocyanidins (total condensed tannins) measured from halophyte biomasses. Studies that used a vanillin assay applied the method by Sun et al. [30], except ChekrounBechlaghemt et al. [31], who used the modified method by Julkunen-Tiitto [36].

\begin{tabular}{|c|c|c|c|c|}
\hline Plant Species & Solvent & Method & $\begin{array}{l}\text { Concentration } \\
\text { [mgCE/gDM] }\end{array}$ & Ref. \\
\hline Arthrocnemum macrostachyum & Water & Vanillin assay & $7.50 \pm 0.80$ & [31] \\
\hline Aster tripolium & Acetone $(80 \%)$ & DMACA-HCl & Not detected & [3] \\
\hline Cakile maritimum & Methanol & Vanillin assay & $14.94 \pm 0.04$ & [37] \\
\hline Carpobrotus edulis & Ethanol & DMACA-HCl & $20.3 \pm 0.98$ & [33] \\
\hline Cladium mariscus & Acetone $(80 \%)$ & DMACA-HCl & $38.7 \pm 2.21$ & [3] \\
\hline
\end{tabular}


Table 1. Cont.

\begin{tabular}{|c|c|c|c|c|}
\hline Plant Species & Solvent & Method & $\begin{array}{l}\text { Concentration } \\
\text { [mgCE/gDM] }\end{array}$ & Ref. \\
\hline \multirow{2}{*}{ Crithmum maritimum } & $\mathrm{n} / \mathrm{a}$ & $\mathrm{n} / \mathrm{a}$ & $1.06 \pm 0.77$ & [38] \\
\hline & Acetone $(80 \%)$ & \multirow{7}{*}{ Vanillin assay } & 0.63 & [39] \\
\hline Inula crithmoides & Acetone $(80 \%)$ & & 0.95 & [39] \\
\hline Ipomoea pes-caprae & Methanol (80\%) & & $19.67 \pm 2.54$ & [34] \\
\hline Limonium delicatulum & Methanol (80\%) & & $48.38 \pm 0.75$ & [40] \\
\hline \multirow{3}{*}{ Mesembryanthemum edule } & Methanol & & $14.2 \pm 0.9$ & [28] \\
\hline & Methanol & & $9.51 \pm 1.07$ & [4] \\
\hline & Methanol & & 7.16 & [10] \\
\hline Mesembryanthemum nodiflorum & Methanol & DMACA-HCl & $2.01 \pm 0.04$ & [32] \\
\hline Pluchea lanceolata & Methanol (80\%) & \multirow{3}{*}{ Vanillin assay } & $20.52 \pm 4.32$ & [34] \\
\hline Reaumuria vermiculata & Dichloromethane & & $27.98 \pm 1.01$ & [41] \\
\hline Retama raetam & Acetone $(60 \%)$ & & 10.16 & [42] \\
\hline \multirow{2}{*}{ Salicornia ramosissima } & Acetone $(70 \%)$ & \multirow{2}{*}{ DMACA-HCl } & $32.5 \pm 4.6$ & [5] \\
\hline & Acetone $(80 \%)$ & & Not detected & [3] \\
\hline Salsola kali & Methanol & \multirow{3}{*}{ Vanillin assay } & $2.03 \pm 0.62$ & [43] \\
\hline Salsola vermiculata & Acetone $(80 \%)$ & & Not detected & [3] \\
\hline Salvadora persica & Methanol (80\%) & & $22.35 \pm 2.87$ & [34] \\
\hline Sarcocornia fruticosa & Methanol & DMACA-HCl & $0.46 \pm 0.04$ & [32] \\
\hline Sarcocornia perennis & Methanol & \multirow{4}{*}{ Vanillin assay } & 1.09 & [44] \\
\hline \multirow{3}{*}{ Suaeda fruticosa } & Methanol & & $7.76 \pm 0.28$ & [31] \\
\hline & Methanol (80\%) & & $15.76 \pm 1.43$ & [34] \\
\hline & Acetone & & $1.50 \pm 0.13$ & [45] \\
\hline Suaeda maritima & Methanol & DMACA-HCl & $1.21 \pm 0.05$ & [32] \\
\hline Tamarix africana & Water & \multirow{3}{*}{ Vanillin assay } & $118.43 \pm 11.79$ & [31] \\
\hline Tamarix gallica & Methanol & & $17.28 \pm 1.95$ & [35] \\
\hline Thespesia populnea & Methanol (80\%) & & $20.14 \pm 3.54$ & [34] \\
\hline
\end{tabular}

\section{Phenolic Compounds}

Phenols are a diverse group of phytochemicals which include phenolic acids (hydroxybenzoic acids and hydroxycinnamic acids) and flavonoids, amongst other types of compounds [32]. They are potent antioxidants linked to various health benefits, such as anti-inflammatory, anti-obesity, and even anti-cancer properties [11,46]. They have also been shown to prevent cardiovascular diseases and diabetes [46].

Phenolic compounds can be extracted with water, polar organic solvents, and their mixtures [46]. The colourimetric Folin-Ciocalteu method is well established and commonly used to estimate total phenols in plant extracts. In this method, gallic acid is used to determine a reference curve, and total phenols are measured as an amount of gallic acid equivalent (GAE) in the dried extract. The protocols use Folin-Ciocalteu reagent to measure absorbance at $760 \mathrm{~nm}$, and the process is well described by Singleton and Rossi [47] and Dewanto et al. [48]. The total phenols found in halophyte extract are summarised in Table 2. The concentration of phenols may vary between different parts of a plant, and Ksouri et al. [35] and Medini et al. [40] have shown that phenol content is highest in extracts obtained from flowers. The concentration of phenolic compounds depends on biological factors, such as genotype, the part of the plant, and environmental conditions, such as 
temperature, salinity, water stress, and light intensity [10]. Therefore, the composition extracts from the same species can vary, as can be seen in methanol extracts of Salicornia ramosissima and Tamarix gallica.

Table 2. Total phenolics measured from halophyte extracts with the Folin-Ciocalteu method. Chekroun-Bechlaghem et al. [31] Stankovic et al. [49], Qasim et al. [26], Lopes et al. [3], Rodrigues et al. [50], Lima et al. [5], Pereira et al. [51], Zengin et al. [52], and Castañeda-Loaiza et al. [32] used method by Singleton and Rossi [47]. Hamdoon et al. [53] used the method by Quy et al. [54]. Other studies use the protocol by Dewanto et al. [48].

\begin{tabular}{|c|c|c|c|c|}
\hline Plant Species & Solvent & Method & $\begin{array}{c}\text { Concentration } \\
\text { [mgCAE/gDM] }\end{array}$ & Ref. \\
\hline Artemisia santonicum & Methanol & \multirow{33}{*}{ Folin-Ciocalteu } & $212.71 \pm 0.68$ & [49] \\
\hline \multirow{2}{*}{ Arthrocnemum macrostachyum } & Water & & $10.24 \pm 0.01$ & [31] \\
\hline & Ethyl acetate & & $29.54 \pm 0.78$ & [52] \\
\hline \multirow{2}{*}{ Aster tripolium } & Acetone $(80 \%)$ & & $223 \pm 2.63$ & [3] \\
\hline & Methanol & & $144.75 \pm 0.59$ & [49] \\
\hline Cladium mariscus & Acetone $(80 \%)$ & & $254 \pm 2.26$ & [3] \\
\hline Carpobrotus edulis & Ethanol & & $272.82 \pm 5.59$ & [33] \\
\hline \multirow{2}{*}{ Crithmum maritimum } & Acetone $(80 \%)$ & & 7.9 & [39] \\
\hline & Water & & $35.3 \pm 2.98$ & [51] \\
\hline Halimone portulacoides & Ethyl acetate & & $14.59 \pm 0.21$ & [52] \\
\hline Inula crithmoides & Acetone $(80 \%)$ & & 14.1 & [39] \\
\hline Ipomoea pes-caprae & Methanol (80\%) & & $54.21 \pm 2.31$ & [34] \\
\hline Limoniastrum monopetalum & Methanol & & 15.85 & [55] \\
\hline Limonium algarvense & Methanol & & $228 \pm 2$ & [50] \\
\hline Limonium delicatulum & Acetone $(80 \%)$ & & $92.9 \pm 1.45$ & [40] \\
\hline Limonium densiflorum & Methanol & & $56.18 \pm 0.92$ & [56] \\
\hline Lycium shawii & Ethanol (95\%) & & $52.72 \pm 3.17$ & [53] \\
\hline & Water & & $212.2 \pm 4.8$ & [28] \\
\hline Mesembryanthemum edule & Methanol & & $68.75 \pm 1.07$ & [4] \\
\hline & Methanol & & 70.07 & [10] \\
\hline Mesembryanthemum nodiflorum & Methanol & & $6.75 \pm 0.08$ & [32] \\
\hline Pluchea lanceolata & Methanol $(80 \%)$ & & $42.28 \pm 3.58$ & [34] \\
\hline Reaumuria vermiculata & Methanol & & $117.12 \pm 3.31$ & [41] \\
\hline Retama raetam & Water & & 137.0 & [42] \\
\hline Rumex vesicarius & Ethanol (95\%) & & $28.54 \pm 1.13$ & [53] \\
\hline \multirow{3}{*}{ Salicornia europaea } & Ethyl acetate & & $24.46 \pm 0.16$ & [52] \\
\hline & Ethanol/water & & $\sim 11$ & [57] \\
\hline & Methanol & & $58.20 \pm 0.44$ & [49] \\
\hline \multirow{3}{*}{ Salicornia ramosissima } & Acetone $(80 \%)$ & & $74.1 \pm 2.49$ & [3] \\
\hline & Acetone $(80 \%)$ & & $12.9 \pm 1.9$ & [5] \\
\hline & Water & & $15.02 \pm 2.01$ & [58] \\
\hline \multirow{2}{*}{ Salsola kali } & Methanol & & $17.23 \pm 1.0$ & [43] \\
\hline & Methanol & & 17.23 & [10] \\
\hline
\end{tabular}


Table 2. Cont.

\begin{tabular}{|c|c|c|c|c|}
\hline Plant Species & Solvent & Method & $\begin{array}{l}\text { Concentration } \\
\text { [mgCAE/gDM] }\end{array}$ & Ref. \\
\hline Salsola vermiculata & Acetone $(80 \%)$ & \multirow{14}{*}{ Folin-Ciocalteu } & $133 \pm 2.62$ & [3] \\
\hline Salvadora persica & Methanol (80\%) & & $58.23 \pm 3.54$ & [34] \\
\hline Sarcocornia fruticosa & Methanol & & $5.69 \pm 0.06$ & [32] \\
\hline \multirow{4}{*}{ Suaeda fruticosa } & Methanol & & $11.09 \pm 0.08$ & [59] \\
\hline & Acetone & & $31.7 \pm 0.51$ & [45] \\
\hline & Methanol/water & & $47.73 \pm 1.17$ & [31] \\
\hline & Methanol (80\%) & & $46.54 \pm 4.32$ & [34] \\
\hline \multirow{2}{*}{ Suaeda maritima } & Methanol & & $16.6 \pm 0.1$ & [32] \\
\hline & Methanol & & $62.88 \pm 0.88$ & [49] \\
\hline Tamarix africana & Water & & $61.06 \pm 0.40$ & [31] \\
\hline \multirow{2}{*}{ Tamarix gallica } & Methanol & & $135.35 \pm 7.70$ & [35] \\
\hline & Methanol & & 70.56 & [10] \\
\hline Thespesia populnea & Methanol (80\%) & & $63.91 \pm 5.28$ & [34] \\
\hline Zaleya pentandra & Methanol & & $22.60 \pm 0.14$ & {$[60]$} \\
\hline
\end{tabular}

Several different protocols have been established to determine the phenolic profile of plant extracts and measure the concentration of single bioactive compounds using highperformance liquid chromatography (HPLC). The analytical procedure used depends on the compounds of interest; this study presents procedures used in some of the reviewed studies and the main separated compounds detected. Various HPLC methods and phenolic profiles of halophyte extracts has previously been reviewed by Lopes et al. [61]. Rodrigues et al. [50] determined the concentration of phenolic compounds in Limonium algarvense extract with a "Mediterranea sea 18" column, a mixture of methanol and aqueous acetic acid as mobile phase, and a diode array detector (DAD),. The targeted compounds with the highest concentrations were gallic acid $(3.37 \mathrm{mg} / \mathrm{gDM})$, catechin $(2.87 \mathrm{mg} / \mathrm{gDM})$, and salicylic acid (1.89 mg/gDM). However, Medini et al. [32] identified phenolic acids from the closely related Limonium delicatulum by means of reverse-phase HPLC with an RPC18 column, aqueous a trifluoroacetic acid and acetonitrile mobile phase, and a $\mathrm{DAD}$, finding the major compounds to be coumaric acid and chlorogenic acid; however, the compounds were not quantified. Castañeda-Loaiza et al. [32] determined phenolic profile using the same method as Rodrigues et al. [50] and found the dry matter from Mesembryanthemum nodiflorum extract to be rich in ferulic acid $(15.3 \mu \mathrm{g} / \mathrm{mgDW})$ and caffeic acid $(3.85 \mu \mathrm{g} / \mathrm{mgDW})$. In extracts of Suaeda maritima and Sarcocornia fruticosa, the phenolic compounds with the highest concentrations were coumaric acid $(0.98 \mu \mathrm{g} / \mathrm{mgDW})$ and chlorogenic acid $(2.25 \mu \mathrm{g} / \mathrm{mgDW})$, respectively [32]. Mariem et al. [42] identified the major phenolic compounds in Retama raetam as syringic acid and coumarin, using reverse-phase HPLC with an ODS C18 column and a mixture of acetonitrile and sulphuric acid as the mobile phase. Qasim et al. [34] determined the phenolic profile of Ipomoea pes-caprae, finding that the major compounds were chlorogenic acid and gallic acid $(7.37 \pm 0.11 \mathrm{mg} / \mathrm{g}$ and $1.42 \pm 0.07 \mathrm{mg} / \mathrm{g}$, respectively). For Suaeda fruticose, they found major compounds to be catechin and chlorogenic acid (1.67 $\pm 0.08 \mathrm{mg} / \mathrm{g}$ and $1.27 \pm 0.09 \mathrm{mg} / \mathrm{g}$, respectively). Silva et al. [58] used HPLC with a C18 column, a mixture of methanol and water as the mobile phase, and a photodiode array detector (PDA). They found the predominant compound in the extract to be flavonoid myricetin $(0.43 \pm 0.02 \mathrm{mg} / \mathrm{gDM})$. Jdey et al. [62] analysed phenolic compounds with a C18 column, a methanol and formic acid mobile phase, and DAD; they found the total amount of phenolics in Frankeani laevis to be $16 \mathrm{mg} / \mathrm{gDM}$. 


\section{Chlorophylls}

Chlorophylls (chlorophyll $a$ and chlorophyll $b$ ) are photosynthetic pigments responsible for the green colour of plants. In human nutrition, chlorophyll has antioxidant activity, and the rich colour makes products more desirable for consumption [6,63,64]. It has also been shown to have anti-cancer properties, as it can interfere with the absorption of some carcinogenic compounds in the gastrointestinal tract [65]. Chlorophyll-derivative chlorophyllin is also registered as a food additive and natural colourant (E140i), and pigment concentrates can be extracted from edible plants using organic solvents [66].

Most of the studies determine the concentration of pigments as a basis of the dry weight or fresh weight (FW) of the biomass. When considering FW, it is important to note that succulent halophytes, in particular, have a high moisture content which can exceed $80 \%$ of the fresh weight $[6,67]$. The amount of pigment can also be determined based on leaf surface area: Geissler et al. [68] applied this method in their study of photosynthesis of Aster tripolium.

Spectrophotometric methods are widely used to determine the amount of chlorophyll in halophyte extracts. Most of the reviewed studies use the technique introduced by Lichtenthaler et al. [69], where wavelengths are used for measuring absorbance, and the conversion coefficients depend on the solvent used. Duarte et al. [67] and Sghaier et al. [70] used a novel quantification technique after ultrasound-assisted acetone extraction which involved applying the Gauss peak spectra method developed by Küpper et al. [71] instead of traditional spectroscopic methods. Some HPLC methods are also available for pigment determination. The method by Mendes et al. [72] was firstly developed for marine algae biomass, and it uses a C8 column with methanol, acetonitrile, and acetone (50:25:25 v\%) as the mobile phase.

As seen from Table 3, among halophyte species, the highest chlorophyll content in fresh biomass were found in acetone extracts of Salicornia europaea and Salicornia persica (approximately $1.25 \mathrm{mg} / \mathrm{gFW}$ and $2.21 \mathrm{mg} / \mathrm{gFW}$, respectively) [73]. Values are relatively high compared to other species.

Table 3. Total chlorophyll content measured from halophyte biomasses. Studies that used spectrophotometry applied the method by Lichtenthaler et al. [69], except Lu et al. [22], who used the method proposed by Vernon [74]; Ventura et al. [63], who used the method proposed by Arnon et al. [75]; and Barreira et al. [6]. who used the method proposed by Nagata and Yamashita [76].

\begin{tabular}{|c|c|c|c|c|c|}
\hline Plant Species & Solvent & Method & Concentration & Unit & Ref. \\
\hline Arthrocnemum macrostachyum & Acetone/hexane & \multirow{7}{*}{ Spectrophotometry } & $28.3 \pm 7.1$ & $\mathrm{mg} / 100 \mathrm{gDM}$ & [6] \\
\hline Aster tripolium & Ethanol & & $\sim 51$ & $\mathrm{mg} / \mathrm{cm}^{2}$ & [68] \\
\hline Halimione portulacoides & Acetone & & $95.04 \pm 23.47$ & $\mu \mathrm{g} / \mathrm{gFW}$ & [67] \\
\hline Mesembryanthemum nodiflorum & Methanol & & $\sim 280$ & $\mathrm{mg} / 100 \mathrm{gDM}$ & [32] \\
\hline Salicornia bigelovii & Acetone & & $569.1 \pm 9.10$ & $\mathrm{mg} / \mathrm{kgFW}$ & [22] \\
\hline Salicornia brachiata & Acetone & & $746.5 \pm 88.2$ & $\mu \mathrm{g} / \mathrm{gDM}$ & [77] \\
\hline Salicornia europaea & Acetone & & $\sim 1.25$ & $\mathrm{mg} / \mathrm{gFW}$ & [73] \\
\hline Salicornia neei & Methanol & HPLC & $233.3 \pm 42.5$ & $\mu \mathrm{g} / \mathrm{gDM}$ & [78] \\
\hline \multirow{2}{*}{ Salicornia persica } & Acetone & \multirow{11}{*}{ Spectrophotometry } & $\sim 1.21$ & $\mathrm{mg} / \mathrm{gFW}$ & [73] \\
\hline & Acetone & & $\sim 325$ & $\mu \mathrm{g} / \mathrm{gFW}$ & [63] \\
\hline Salicornia prostrata & Acetone & & $\sim 0.14$ & $\mathrm{mg} / \mathrm{gFW}$ & [79] \\
\hline Salicornia ramosissima & Acetone/hexane & & $21.56 \pm 3.45$ & $\mathrm{mg} / 100 \mathrm{gDM}$ & [6] \\
\hline \multirow{3}{*}{ Sarcocornia fruticosa } & Methanol & & $\sim 290$ & $\mathrm{mg} / 100 \mathrm{gDM}$ & [32] \\
\hline & Acetone & & $102.01 \pm 18.23$ & $\mu \mathrm{g} / \mathrm{gFW}$ & [67] \\
\hline & Acetone & & $\sim 350$ & $\mu \mathrm{g} / \mathrm{gFW}$ & [63] \\
\hline Sarcocornia perennis & Acetone/hexane & & $14.78 \pm 2.33$ & $\mathrm{mg} / 100 \mathrm{gDM}$ & {$[6]$} \\
\hline Suaeda maritima & Methanol & & $\sim 280$ & $\mathrm{mg} / 100 \mathrm{gDM}$ & [32] \\
\hline Suaeda prostrata & Acetone & & $\sim 0.08$ & $\mathrm{mg} / \mathrm{gFW}$ & [79] \\
\hline Tamarix gallica & Acetone & & $\sim 180$ & $\mathrm{mg}$ & [70] \\
\hline
\end{tabular}




\section{Carotenoids}

Carotenoids, which can be divided into carotenes (e.g., $\beta$-carotene and lycopene) and xanthophylls (e.g., lutein and zeaxanthin), are potent antioxidants and have various functions in human health, such as pro-vitamin A activity, cancer-preventing properties, and improvements in cognitive function as well as eye and cardiovascular health $[8,11]$. Immunomodulation activities and prevention of degenerative diseases have also been reported as possible health benefits of carotenoids [80]. In plants, these yellow and orange pigments take part in photosynthesis by protecting photosystems [78].

The level of total carotenoids is often approximated by measuring the absorbance of the acetone extract with a $470 \mathrm{~nm}$ wavelength. Conversion calculations depend on the solvent used and whether the calculation focused on the amount of chlorophyll in the extract. Some protocols describing the determination of chlorophyll also include the determination of total carotenoids $[69,76]$. The total carotenoid content measured in the biomass of various halophytes are summarised in Table 4 .

Table 4. Total carotenoid content measured from halophyte biomass. All studies measured the absorbance with $470 \mathrm{~nm}$, except Qasim et al. [34], who used the method by Duxbury and Yentsch [81]; Ventura et al. [63], who used the method by Ben-Amotz et al. [82]; Barreira et al. [26], who used the same method as Uslu et al. [83]; and Kumari et al. [84] and Rangani et al. [85] who used N, $\mathrm{N}$-dimethylformamide (DMF) as a solvent with the method by Chamovitz et al. [86]. The conversion calculations may differ.

\begin{tabular}{|c|c|c|c|c|c|}
\hline Plant Species & Solvent & Method & Concentration & Unit & Ref. \\
\hline Arthrocnemum macrostachyum & Acetone & \multirow{9}{*}{ Spectrophotometry } & $210 \pm 10$ & $\mathrm{mg} / 100 \mathrm{gDM}$ & [6] \\
\hline Aster tripolium & Ethanol & & $\sim 8$ & $\mathrm{mg} / \mathrm{cm}^{2}$ & [68] \\
\hline Halimione portulacoides & Acetone & & $51.47 \pm 17.76$ & $\mu \mathrm{g} / \mathrm{gFW}$ & [67] \\
\hline Ipomoea pes-caprae & Acetone $(90 \%)$ & & $0.61 \pm 0.01$ & $\mathrm{mg} / \mathrm{g}$ & [34] \\
\hline Mesembryanthemum nodiflorum & Methanol & & $\sim 21$ & $\mathrm{mg} / 100 \mathrm{gDM}$ & [32] \\
\hline Pluchea lanceolata & Acetone $(90 \%)$ & & $0.07 \pm 0.02$ & $\mathrm{mg} / \mathrm{g}$ & [34] \\
\hline Salicornia bigelovii & Hexane & & $159.0 \pm 5.74$ & $\mathrm{mg} / \mathrm{kgFW}$ & [22] \\
\hline Salicornia brachiata & Acetone & & $433.8 \pm 46.0$ & $\mu \mathrm{g} / \mathrm{gDM}$ & [77] \\
\hline Salicornia europaea & Acetone & & $\sim 0.43$ & $\mathrm{mg} / \mathrm{gFW}$ & [73] \\
\hline Salicornia neei & Methanol & HPLC & $28.71 \pm 7.52$ & $\mu \mathrm{g} / \mathrm{gDM}$ & [78] \\
\hline \multirow{2}{*}{ Salicornia persica } & Acetone & \multirow{3}{*}{ Spectrophotometry } & $\sim 0.44$ & $\mathrm{mg} / \mathrm{gFW}$ & [73] \\
\hline & Acetone & & 54.5 & $\mu \mathrm{g} / \mathrm{gFW}$ & [63] \\
\hline Salicornia prostrata & Acetone & & $\sim 0.25$ & $\mathrm{mg} / \mathrm{gFW}$ & [79] \\
\hline \multirow{2}{*}{ Salicornia ramosissima } & Ethyl acetate & HPLC & 3.49 & $\mathrm{mg} / 100 \mathrm{gFW}$ & [5] \\
\hline & Acetone & \multirow{13}{*}{ Spectrophotometry } & $290 \pm 20$ & $\mathrm{mg} / 100 \mathrm{gDM}$ & [6] \\
\hline \multirow{2}{*}{ Salvadora persica } & Acetone $(90 \%)$ & & $0.84 \pm 0.02$ & $\mathrm{mg} / \mathrm{g}$ & [34] \\
\hline & DMF & & $11.4 \pm 2.5$ & $\mu \mathrm{g} / 100 \mathrm{gDM}$ & [84] \\
\hline \multirow{3}{*}{ Sarcocornia fruticosa } & Methanol & & $\sim 16$ & $\mathrm{mg} / 100 \mathrm{gDM}$ & [32] \\
\hline & Acetone & & 56.6 & $\mu \mathrm{g} / \mathrm{gFW}$ & [63] \\
\hline & Acetone & & $34.76 \pm 9.03$ & $\mu \mathrm{g} / \mathrm{gFW}$ & [67] \\
\hline Sarcocornia perennis & Acetone & & $280 \pm 10$ & $\mathrm{mg} / 100 \mathrm{gDM}$ & [6] \\
\hline Suaeda fruticosa & Acetone $(90 \%)$ & & $0.56 \pm 0.01$ & $\mathrm{mg} / \mathrm{g}$ & {$[34]$} \\
\hline Suaeda maritima & Methanol & & $\sim 12$ & $\mathrm{mg} / 100 \mathrm{gDM}$ & [32] \\
\hline Suaeda prostrata & Acetone & & $\sim 0.19$ & $\mathrm{mg} / \mathrm{gFW}$ & [79] \\
\hline Tamarix gallica & Acetone & & $\sim 70$ & $\mathrm{mg}$ & [70] \\
\hline \multirow{2}{*}{ Thespesia populnea } & Acetone $(90 \%)$ & & $0.72 \pm 0.02$ & $\mathrm{mg} / \mathrm{g}$ & [34] \\
\hline & DMF & & $233.5 \pm 5.3$ & $\mathrm{mg} / 100 \mathrm{gDM}$ & [85] \\
\hline
\end{tabular}


De Souza et al. [78] determined the detailed pigment content of Salicornia neei using ultrasound-assisted methanol extraction and the HPLC method proposed by Mendes et al. [72]. They found the $\beta$-carotene and the total xanthophyll content of Salicornia neei biomass to be $0.99 \pm 0.41 \mu \mathrm{g} / \mathrm{gDM}$ and $27.72 \pm 7.12 \mu \mathrm{g} / \mathrm{gDM}$, respectively. Additionally, Lima et al. [5] used HPLC with a reverse-phase RP-18 column and PDA in several wavelengths for the determination of pigments and vitamins from Salicornia ramosissima biomass and found $2.37 \pm 0.12 \mathrm{mg} / 100 \mathrm{gFW}$ and $1.12 \pm 0.05 \mathrm{mg} / 100 \mathrm{gFW}$ of $\beta$-carotene and lutein, respectively. Alongside measuring the total carotenoids using a spectrophotometric method, Castañeda-Loaiza et al. [32] determined the amount of carotenes in the methanol extracts using HPLC with a RP-18 column and a PDA in $450 \mathrm{~nm}$, finding Sarcocornia fruticosa, Suaeda maritima, and Mesembryanthemum nodiflorum to be good sources of lutein (8.89-19.7 mg/100 gDM) and latter two also good sources of $\beta$-carotene (9.30-20.7 mg/100 gDW).

Duarte et al. [67] determined the carotenoid content of Halimone portulacoides and Sarcocornia fruticosa and found that concentrations of $\beta$-carotene $(7.60 \pm 2.06 \mu \mathrm{g} / \mathrm{gFW}$ and $5.53 \pm 0.94 \mu \mathrm{g} / \mathrm{gFW}$, respectively), lutein $(17.09 \pm 6.04 \mu \mathrm{g} / \mathrm{gFW}$ and $14.93 \pm 3.91 \mu \mathrm{g} / \mathrm{gFW}$, respectively) and other xanthophylls $(26.78 \pm 9.66 \mu \mathrm{g} / \mathrm{gFW}$ and $14.09 \pm 4.18 \mu \mathrm{g} / \mathrm{gFW}$, respectively) decreased when the plants were exposed to salt stress due to lengthened period of relatively high temperatures in harvest region. The opposite effect was observed in salt-stressed Salicornia ramosissima in the study by Lima et al. [5], which suggests the higher carotenoid content in biomass may be caused by the increased antioxidant capacity to protect photosystems from photo-oxidation.

\section{Vitamins}

Vitamins are essential nutrients to ensure average growth and human health. They are a diverse group of organic compounds, classified either as water-soluble (vitamins $B$ and C) or fat-soluble (vitamins A, D, E, and K) [80]. Vitamins have various biochemical roles, and they are already highly commercialised as nutraceutical and functional food additives [80]. Vegetables, fruits, unrefined cereals, seeds, and nuts are key sources of vitamins for humans [87].

Compared to other studied compounds, a large variety of methods are used to analyse vitamin concentrations. Hexane and ethyl acetate are commonly used solvents for the extraction of lipid-soluble vitamins. A wider variety of solvents are used for the extraction of water-soluble compounds. Castañeda-Loaiza et al. [32] and Lima et al. [5] use the extraction and analytical methods proposed by Santos et al. [88] for fat-soluble and watersoluble vitamins. Various HPLC methods involving a photodiode array detector (PDA) or fluorescence detector (FL) are widely used; only Chamkouri et al. [89] use a DAD and Zaier et al. [90] an ultraviolet (UV) detector in their analytical methods.

Ascorbic acid (vitamin C) is an essential nutrient for humans and other animals. Humans cannot synthesise vitamin C, and deficiency due to insufficient intake can cause scurvy disease $[80,87]$. It has also been reported to help maintain the integrity of cellular membranes and improve skin health [84,85]. It is a co-factor for enzyme reactions and a potent antioxidant which has been shown to have a preventive effect on various chronic conditions [91]. It has also been reported to improve skin health $[84,85]$.

Ascorbic acid degrades relatively fast, and a study by Lu et al. [22] showed a gradual decrease in the ascorbic acid content of Salicornia bigelovii during storage: $56 \%$ of ascorbic acid was lost after eight days at $0{ }^{\circ} \mathrm{C}$. The succulent Amaranthaceae family halophytes Arthrocnemum indicum, Halocnemum strobilaceum, and Salicornia bigelovii have been found to be rich in ascorbic acid [22,90]. Kumari et al. [84] also found considerably high amounts of vitamin C from Salvadora persica fruit. Rangani et al. [85] also suggest that the ascorbic acid content in Thespesia populnea leaves is enough to fulfil the daily requirements of a healthy individual.

Compounds considered as B complex vitamins are antioxidants and essential coenzymes, supporting vital biological processes $[80,89]$. For example, thiamine (B1) is 
essential to carbohydrate metabolism, pyridoxine (B6) to protein metabolism, folate (B9) to the synthesis of nucleic acids, and cobalamin (B12) for the nervous system, cell growth, and bone health $[5,89]$.

Chamkouri et al. [89] developed an optimised analytical method to measure the vitamin in B complex in halophyte extracts and suggested that Suaeda aegyptiaca and Suaeda vera may be promising sources for the production of health-beneficial products for food and pharmaceuticals. Suaeda aegyptiaca, in particular, was found to be a significant source of cobalamin [89], with concentrations being higher than in sea buckthorn [92], making it desirable for people following a strictly plant-based diet and who are at risk of vitamin B12 deficiency. The amounts of water-soluble vitamins (vitamin $C$ and $B$ complex vitamins) found in the biomass of various halophytes are summarised in Table 5.

Table 5. Ascorbic acid (vitamin C) and thiamine, pyridoxine, folate, and cobalamin (vitamin B1, B6, B9, and B12, respectively) concentrations measured in halophyte biomasses. The analysed vitamin is marked in parentheses after its concentration.

\begin{tabular}{|c|c|c|c|c|c|}
\hline Plant Species & Solvent & Method & Concentration & Unit & Ref. \\
\hline Arthrocnemum indicum & m-Phosphoric acid (4.5\%) & \multirow{2}{*}{ HPLC-UV } & $19.17 \pm 0.50(\mathrm{C})$ & $\mathrm{mg} / 100 \mathrm{gFW}$ & \multirow{2}{*}{ [90] } \\
\hline Halocnemum strobilaceum & m-Phosphoric acid (4.5\%) & & $7.38 \pm 0.54(\mathrm{C})$ & $\mathrm{mg} / 100 \mathrm{gFW}$ & \\
\hline \multirow{2}{*}{ Mesembryanthemum nodiflorum } & \multirow{2}{*}{$\begin{array}{l}\text { Ammonium } \\
\text { acetate/methanol (50:50) }\end{array}$} & \multirow{2}{*}{ HPLC-PDA } & $\sim 0.5(\mathrm{C})$ & $\mathrm{g} / 100 \mathrm{gDM}$ & \multirow{2}{*}{ [32] } \\
\hline & & & $\sim 24$ (B6) & $\mathrm{mg} / 100 \mathrm{gDM}$ & \\
\hline Salicornia bigelovii & Oxalic acid solution & Indophenol titration & $58.4 \pm 1.39(\mathrm{C})$ & $\mathrm{mg} / \mathrm{kgFW}$ & [22] \\
\hline \multirow{2}{*}{ Salicornia ramosissima } & \multirow{2}{*}{$\begin{array}{c}\text { Ammonium } \\
\text { acetate/methanol (50:50) }\end{array}$} & \multirow{2}{*}{ HPLC-PDA } & $30.4 \pm 2.0(\mathrm{~B} 1)$ & $\mu \mathrm{g} / 100 \mathrm{gFW}$ & \multirow{2}{*}[5]{} \\
\hline & & & $2.6 \pm 0.1(\mathrm{~B} 6)$ & $\mu \mathrm{g} / 100 \mathrm{gFW}$ & \\
\hline Salvadora persica & Trichloroacetic acid (6\%) & Spectrophotometry & $68.0 \pm 15.9(\mathrm{C})$ & $\mathrm{mg} / 100 \mathrm{gDM}$ & [84] \\
\hline \multirow{2}{*}{ Sarcocornia fruticosa } & \multirow{2}{*}{$\begin{array}{c}\text { Ammonium } \\
\text { acetate/methanol (50:50) }\end{array}$} & \multirow{2}{*}{ HPLC-PDA } & $\sim 1.0(\mathrm{C})$ & $\mathrm{g} / 100 \mathrm{gDM}$ & \multirow{2}{*}{ [32] } \\
\hline & & & $\sim 10$ (B6) & $\mathrm{mg} / 100 \mathrm{gDM}$ & \\
\hline \multirow{3}{*}{ Suaeda aegyptiaca } & \multirow{3}{*}{ Methanol } & \multirow{3}{*}{ HPLC-DAD } & $181 \pm 2.3(\mathrm{~B} 6)$ & $\mathrm{mg} / \mathrm{kg}$ & \multirow{3}{*}{ [89] } \\
\hline & & & $118 \pm 2.2(\mathrm{~B} 9)$ & $\mathrm{mg} / \mathrm{kg}$ & \\
\hline & & & $466 \pm 2.5(\mathrm{~B} 12)$ & $\mathrm{mg} / \mathrm{kg}$ & \\
\hline Suaeda fruticosa & m-Phosphoric acid (4.5\%) & HPLC-UV & $2.46 \pm 0.07(\mathrm{C})$ & $\mathrm{mg} / 100 \mathrm{gFW}$ & [90] \\
\hline \multirow{2}{*}{ Suaeda matritima } & \multirow{2}{*}{$\begin{array}{c}\text { Ammonium } \\
\text { acetate/methanol (50:50) }\end{array}$} & \multirow{2}{*}{ HPLC-PDA } & $\sim 3(\mathrm{C})$ & $\mathrm{g} / 100 \mathrm{gDM}$ & \multirow{2}{*}{ [32] } \\
\hline & & & $\sim 9.5$ (B6) & $\mathrm{mg} / 100 \mathrm{gDM}$ & \\
\hline \multirow{3}{*}{ Suaeda vera } & \multirow{3}{*}{ Methanol } & \multirow{3}{*}{ HPLC-DAD } & $102 \pm 1.4(\mathrm{~B} 6)$ & $\mathrm{mg} / \mathrm{kg}$ & \multirow{3}{*}{ [89] } \\
\hline & & & $118 \pm 2.2(\mathrm{~B} 9)$ & $\mathrm{mg} / \mathrm{kg}$ & \\
\hline & & & $271 \pm 1.7(\mathrm{~B} 12)$ & $\mathrm{mg} / \mathrm{kg}$ & \\
\hline Thespesia populnea & Trichloroacetic acid (6\%) & Spectrophotometry & $44.3 \pm 5.5(\mathrm{C})$ & $\mathrm{mg} / 100 \mathrm{gDM}$ & [85] \\
\hline
\end{tabular}

Tocopherols (vitamin E) are lipid-soluble antioxidants, and their radical scavenging activity protects cell membranes, lipoproteins, and other molecules against lipid peroxidation caused by oxidative stress $[6,11]$. Improved cardiovascular health, prevention of degenerative disorders, and anti-cancer properties are also reported as potential health benefits of tocopherols [80]. Tocopherols are present in different isomers, $\alpha$-tocopherol being reported as the most abundant in halophyte biomasses [11].

Ellouzi et al. [93] studied the effect of salt stress on the $\alpha$-tocopherol content of glycophyte (Arabidopsis thaliana) and halophyte (Cakile maritima) species. They found the vitamin E content of glycophytes decreases by $50 \%$ soon after being exposed to salt, whereas the vitamin levels of halophyte plants remained significantly higher throughout the cultivation period. Barreira et al. [6] found high concentrations of $\alpha$-tocopherol in Arthrocnemum macrostachyum shoots, making it a good source of vitamin E, similarly to other green vegetables, such as kale and broccoli. The concentration of $\alpha$-tocopherol measured in halophyte biomasses is summarised in Table 6. Significant variations in vitamin E content are possible 
between species within the same genus, which can be seen in the reported results, for example, in Sarcocornia and Suaeda species.

Table 6. $\alpha$-Tocopherol (vitamin E) concentrations measured from halophyte biomasses.

\begin{tabular}{|c|c|c|c|c|c|}
\hline Plant Species & Solvent & Method & Concentration & Unit & Ref. \\
\hline Arthrocnemum indicum & Hexane & \multirow{4}{*}{ HPLC-FL } & $2.12 \pm 0.01$ & $\mathrm{mg} / 100 \mathrm{gFW}$ & [39] \\
\hline Arthrocnemum macrostachyum & Hexane & & $8.74 \pm 0.19$ & $\mathrm{mg} / 100 \mathrm{gDM}$ & [6] \\
\hline Cakile maritima & Methanol & & $\sim 200$ & $\mu \mathrm{g} / \mathrm{gDM}$ & [93] \\
\hline Halocnemum strobilaceum & Hexane & & $3.35 \pm 0.08$ & $\mathrm{mg} / 100 \mathrm{gFW}$ & [90] \\
\hline Mesembryanthemum nodiflorum & Ethyl acetate & \multirow{2}{*}{ HPLC-PDA } & Not detected & & [32] \\
\hline \multirow{2}{*}{ Salicornia ramosissima } & Ethyl acetate & & $241 \pm 10$ & $\mu \mathrm{g} / 100 \mathrm{gFW}$ & {$[5]$} \\
\hline & Hexane & HPLC-FL & $1.14 \pm 0.07$ & $\mathrm{mg} / 100 \mathrm{gDM}$ & [6] \\
\hline Sarcocornia fruticosa & Ethyl acetate & HPLC-PDA & $\sim 18$ & $\mathrm{mg} / 100 \mathrm{gDM}$ & [32] \\
\hline Sarcocornia perennis & Hexane & \multirow{2}{*}{ HPLC-FL } & $1.11 \pm 0.10$ & $\mathrm{mg} / 100 \mathrm{gDM}$ & [6] \\
\hline Suaeda fruticosa & Hexane & & $11.42 \pm 0.14$ & $\mathrm{mg} / 100 \mathrm{gFW}$ & [90] \\
\hline Suaeda matritima & Ethyl acetate & HPLC-PDA & $\sim 12.5$ & $\mathrm{mg} / 100 \mathrm{gDM}$ & [32] \\
\hline Teucrium alopecurus & Hexane & \multirow{3}{*}{ HPLC-FL } & 316.25 & $\mathrm{mg} / \mathrm{kg}$ & [94] \\
\hline Teucrium polium & Hexane & & 277.25 & $\mathrm{mg} / \mathrm{kg}$ & [94] \\
\hline Teucrium nabli & Hexane & & 296.04 & $\mathrm{mg} / \mathrm{kg}$ & [94] \\
\hline
\end{tabular}

Concerning another fat-soluble compound, retinyl acetate (vitamin A), CastañedaLoaiza et al. [32] found concentrations of $4.51 \mathrm{mg} / 100 \mathrm{gDM}$ and $5.39 \mathrm{mg} / 100 \mathrm{gDM}$ in Mesembryanthemum nodiflorum and Suaeda matritima, respectively. No other studies were found to measure the vitamin A content in halophytes. However, the most important plantbased vitamin A intake for humans comes from the pro-vitamin A activity of carotenoids, mainly $\beta$-carotene [95].

Changes in environmental conditions influence plants, and some halophytes exhibit changes in their colour as an adaptation to the stress caused by high UV radiation, temperature, or salinity, factors which also affect the plants' chemical composition, as shown by Zaier et al. [90]. Studies have shown that the phenotypic stage (green or red-purple) has a significant effect on the ascorbic acid content of Suaeda fruticosa and the $\alpha$-tocopherol content of Suaeda fruticosa and Arthocnemum indicum [90]. As the red-purple phenotype has a lower concentration of these vitamins [90], the possible loss of health-beneficial compounds should be considered when planning the cultivation and harvest of halophytes. Lima et al. [5] studied the effect of cultivation salinity on the nutritional composition of Salicornia ramosissima and reported that higher salinity led to a significant increase in thiamine content but a decrease in pyridoxine and $\alpha$-tocopherol content.

\section{Potential Applications}

As suggested in Figure 1, potential applications for botanical extracts obtained from biorefinery could include bio-functional feed and nutraceuticals, cosmetics, and even biomedicines. This is due to various health-beneficial properties and bioactivities of the compounds found in such extracts. Halophytes can provide a healthy and nutritious food source, but botanical extracts could also be utilized in bio-functional food and nutraceuticals $[6,22,23,32]$. Sufficient consumption of phytochemicals, especially phenolic compounds, has been shown to reduce oxidative stress and inflammation, which helps prevent diabetes, cardiovascular diseases, and neurodegenerative diseases $[27,29,34,56]$. The state-of-the-art literature review concerning the bioactive secondary metabolites in halophytes shows that many species are rich in these protective compounds and vitamins, which are essential nutrients for human health. 
Botanical extracts are commonly used as cosmetics ingredients, and the potential of halophyte extracts for the cosmetics industry has been reported $[2,3,11,39,96]$. Extracts are often used in cosmetics due to their antioxidant activity, but anti-ageing, photoprotective, and skin-whitening properties of halophyte extracts have also been reported [61,96-99].

In some applications, such as utilizing specific pharmacological compounds, it is desirable to isolate specific compounds from botanical extracts. This can be done with filtration or serial solvent extractions when the characteristics of the targeted compounds are known [100], and some of the commercialized plant extracts used for pharmacological purposes have a high market value [101]. However, in plant extracts, various compounds found in the matrix work together and single compounds are rarely responsible for the bioactivity of the botanical extract [100]. Anti-inflammatory effects, radical-scavenging activity, and cytotoxicity have made halophyte extracts interesting for pharmaceutical applications [2,13,41,102,103]. Many studies have also reported the antimicrobial effect of halophyte extracts against pathogenic strains, making them interesting for the biomedicine industry $[2,11,35,40,55,61,104]$.

\section{Conclusions}

The studies reviewed here show that halophyte biomasses have the potential for nutrient-rich food production in salt-affected areas as well as production of nutraceuticals and ingredients for cosmetics and pharmaceutical industries. Many studies concern the nutritional profile of fresh plants.

The food harvest period for succulent halophyte tips is short, as the shrubs lignify and turn woodier as they mature, making them unpleasant to eat. Leftover shrubs are usually considered agricultural waste. Therefore, to minimise the competition with food resources, it could be desirable to analyse these partly lignified, non-food grade but still-succulent remains for their potential for producing nutraceuticals, bio-functional feed, and other high-value compounds.

Exploring new biomasses and the repurposing of remnants previously seen as waste could help identify new bio-derived sources for valuable compounds and improve the sustainability and economic feasibility of existing production systems. In addition, utilising salt-tolerant plants could bring more value to salt-affected areas which are currently unsuitable for farming and considered marginal lands.

Author Contributions: Writing—original draft preparation, L.S.S.H.; writing-review and editing, T.C. and M.H.T.; supervision, M.H.T. All authors have read and agreed to the published version of the manuscript.

Funding: This study has received funding from the European Union's Horizon 2020 research and innovation programme under Grant Agreement No 862834. Any results of this project reflect only this consortium's view; the European Commission is not responsible for any use that may be made of the information it contains.

Institutional Review Board Statement: Not applicable.

Conflicts of Interest: The authors declare no conflict of interest.

\section{References}

1. EIP-AGRI Focus Group Soil Salinisation: Final report. Publisher EIP Agri. 2020. Available online: https:/ / ec.europa.eu/eip/ agriculture/en/publications/eip-agri-focus-group-soil-salinisation-final (accessed on 3 January 2022).

2. Giordano, R.; Saii, Z.; Fredsgaard, M.; Hulkko, L.S.S.; Poulsen, T.B.G.; Thomsen, M.E.; Henneberg, N.; Zucolotto, S.M.; ArendtNielsen, L.; Papenbrock, J.; et al. Pharmacological insights into halophyte bioactive extract action on anti-inflammatory, pain relief and antibiotics-type mechanisms. Molecules 2021, 26, 3140. [CrossRef]

3. Lopes, A.; Rodrigues, M.J.; Pereira, C.; Oliveira, M.; Barreira, L.; Varela, J.; Trampetti, F.; Custódio, L. Natural products from extreme marine environments: Searching for potential industrial uses within extremophile plants. Ind. Crops Prod. 2016, 94, 299-307. [CrossRef]

4. Falleh, H.; Ksouri, R.; Medini, F.; Guyot, S.; Abdelly, C.; Magné, C. Antioxidant activity and phenolic composition of the medicinal and edible halophyte Mesembryanthemum edule L. Ind. Crops Prod. 2011, 34, 1066-1071. [CrossRef] 
5. $\quad$ Lima, A.R.; Castañeda-Loaiza, V.; Salazar, M.; Nunes, C.; Quintas, C.; Gama, F.; Pestana, M.; Correia, P.J.; Santos, T.; Varela, J.; et al. Influence of cultivation salinity in the nutritional composition, antioxidant capacity and microbial quality of Salicornia ramosissima commercially produced in soilless systems. Food Chem. 2020, 333, 127525. [CrossRef]

6. Barreira, L.; Resek, E.; Rodrigues, M.J.; Rocha, M.I.; Pereira, H.; Bandarra, N.; da Silva, M.M.; Varela, J.; Custódio, L. Halophytes: Gourmet food with nutritional health benefits? J. Food Compos. Anal. 2017, 59, 35-42. [CrossRef]

7. Rauf, A.; Imran, M.; Abu-Izneid, T.; Iahtisham-Ul-Haq; Patel, S.; Pan, X.; Naz, S.; Sanches Silva, A.; Saeed, F.; Rasul Suleria, H.A. Proanthocyanidins: A comprehensive review. Biomed. Pharmacother 2019, 116, 108999. [CrossRef] [PubMed]

8. Eggersdorfer, M.; Wyss, A. Carotenoids in human nutrition and health. Arch. Biochem. Biophys. 2018, 652, 18-26. [CrossRef] [PubMed]

9. Cybulska, I.; Brudecki, G.P.; Brown, J.J.; Hulkko, L.S.S.; Al Hosani, S.; Hedegaard Thomsen, M. Comparative study of chemical composition of the halophyte species native to the Persian (Arabian) gulf. BioResources 2021, 16, 5524-5537. [CrossRef]

10. Ksouri, R.; Megdiche, W.; Falleh, H.; Trabelsi, N.; Boulaaba, M.; Smaoui, A.; Abdelly, C. Influence of biological, environmental and technical factors on phenolic content and antioxidant activities of Tunisian halophytes. Comptes Rendus Biol. 2008, 331, 865-873. [CrossRef]

11. Ksouri, R.; Ksouri, W.M.; Jallali, I.; Debez, A.; Magné, C.; Hiroko, I.; Abdelly, C. Medicinal halophytes: Potent source of health promoting biomolecules with medical, nutraceutical and food applications. Crit. Rev. Biotechnol. 2012, 32, 289-326. [CrossRef] [PubMed]

12. Chaturvedi, T.; Christiansen, A.H.C.; Gołębiewska, I.; Thomsen, M.H. Salicornia Species: Current Status and Future Potential. In Future of Sustainable Agriculture in Saline Environments; CRC Press: Boca Raton, FL, USA, 2021; pp. 461-482.

13. Cybulska, I.; Brudecki, G.P.; Alassali, A.; Thomsen, M.H.; Brown, J.J. Phytochemical composition of some common coastal halophytes of the United Arab Emirates. Emirates J. Food Agric. 2014, 26, 1046-1056. [CrossRef]

14. Abdal, M.S. Salicornia production in Kuwait. World Appl. Sci. J. 2009, 6, 1033-1038.

15. Belal, I.E.H.; Al-Dosari, M. Replacement of Fish Meal with Salicornia Meal in Feeds for Nile Tilapia Oreochromis niloticus. $J$. World Aquac. Soc. 1999, 30, 285-289. [CrossRef]

16. Cybulska, I.; Chaturvedi, T.; Brudecki, G.P.; Kádár, Z.; Meyer, A.S.; Baldwin, R.M.; Thomsen, M.H. Chemical characterization and hydrothermal pretreatment of Salicornia bigelovii straw for enhanced enzymatic hydrolysis and bioethanol potential. Bioresour. Technol. 2014, 153, 165-172. [CrossRef] [PubMed]

17. Turcios, A.E.; Weichgrebe, D.; Papenbrock, J. Effect of salt and sodium concentration on the anaerobic methanisation of the halophyte Tripolium pannonicum. Biomass Bioenergy 2016, 87, 69-77. [CrossRef]

18. Bañuelos, J.A.; Velázquez-Hernández, I.; Guerra-Balcázar, M.; Arjona, N. Production, characterization and evaluation of the energetic capability of bioethanol from Salicornia Bigelovii as a renewable energy source. Renew. Energy 2018, 123, 125-134. [CrossRef]

19. Alassali, A.; Cybulska, I.; Galvan, A.R.; Thomsen, M.H. Wet fractionation of the succulent halophyte Salicornia sinus-persica, with the aim of low input (water saving) biorefining into bioethanol. Appl. Microbiol. Biotechnol. 2017, 101, 1769-1779. [CrossRef]

20. Cybulska, I.; Chaturvedi, T.; Alassali, A.; Brudecki, G.P.; Brown, J.J.; Sgouridis, S.; Thomsen, M.H. Characterization of the chemical composition of the halophyte salicornia bigelovii under cultivation. Energy Fuels 2014, 28, 3873-3883. [CrossRef]

21. Martins-Noguerol, R.; Cambrollé, J.; Mancilla-Leytón, J.M.; Puerto-Marchena, A.; Muñoz-Vallés, S.; Millán-Linares, M.C.; Millán, F.; Martínez-Force, E.; Figueroa, M.E.; Pedroche, J.; et al. Influence of soil salinity on the protein and fatty acid composition of the edible halophyte Halimione portulacoides. Food Chem. 2021, 352, 129370. [CrossRef]

22. Lu, D.; Zhang, M.; Wang, S.; Cai, J.; Zhou, X.; Zhu, C. Nutritional characterization and changes in quality of Salicornia bigelovii Torr. during storage. LWT Food Sci. Technol. 2010, 43, 519-524. [CrossRef]

23. Agudelo, A.; Carvajal, M.; del Martinez-Ballesta, M.C. Halophytes of the Mediterranean Basin-Underutilized Species with the Potential to Be Nutritious Crops in the Scenario of the Climate Change. Foods 2021, 10, 119. [CrossRef]

24. Christiansen, A.H.C.; Lyra, D.A.; Jørgensen, H. Increasing the value of Salicornia bigelovii green biomass grown in a desert environment through biorefining. Ind. Crops Prod. 2020, 113105. [CrossRef]

25. Thomsen, M.H.; Alassali, A.; Cybulska, I.; Yousef, A.F.; Brown, J.J.; Andersen, M.; Ratkov, A.; Kiel, P. Microorganisms for Biorefining of Green Biomass; Springer: Berlin/Heidelberg, Germany, 2015; pp. 157-181.

26. De Hoyos-Martínez, P.L.; Merle, J.; Labidi, J.; Charrier-El Bouhtoury, F. Tannins extraction: A key point for their valorization and cleaner production. J. Clean. Prod. 2019, 206, 1138-1155. [CrossRef]

27. Kruger, M.J.; Davies, N.; Myburgh, K.H.; Lecour, S. Proanthocyanidins, anthocyanins and cardiovascular diseases. Food Res. Int. 2014, 59, 41-52. [CrossRef]

28. Falleh, H.; Ksouri, R.; Boulaaba, M.; Guyot, S.; Abdelly, C.; Magne, C. Phenolic nature, occurrence and polymerization degree as marker of environmental adaptation in the edible halophyte Mesembryanthemum edule. S. Afr. J. Bot. 2012, 79, 117. [CrossRef]

29. Smeriglio, A.; Barreca, D.; Bellocco, E.; Trombetta, D. Proanthocyanidins and hydrolysable tannins: Occurrence, dietary intake and pharmacological effects. Br. J. Pharmacol. 2017, 174, 1244-1262. [CrossRef] [PubMed]

30. Sun, B.; Ricardo-da-Silva, J.M.; Spranger, I. Critical Factors of Vanillin Assay for Catechins and Proanthocyanidins. J. Agric. Food Chem. 1998, 46, 4267-4274. [CrossRef] 
31. Chekroun-Bechlaghem, N.; Belyagoubi-Benhammou, N.; Belyagoubi, L.; Gismondi, A.; Nanni, V.; Di Marco, G.; Canuti, L.; Canini, A.; El Haci, I.A.; Atik Bekkara, F. Phytochemical analysis and antioxidant activity of Tamarix africana, Arthrocnemum macrostachyum and Suaeda fruticosa, three halophyte species from Algeria. Plant Biosyst. Int. J. Deal. Asp. Plant Biol. 2019, 153, 843-852. [CrossRef]

32. Castañeda-Loaiza, V.; Oliveira, M.; Santos, T.; Schüler, L.; Lima, A.R.; Gama, F.; Salazar, M.; Neng, N.R.; Nogueira, J.M.F.; Varela, J.; et al. Wild vs cultivated halophytes: Nutritional and functional differences. Food Chem. 2020, 333, 127536. [CrossRef]

33. Castañeda-Loaiza, V.; Placines, C.; Rodrigues, M.J.; Pereira, C.; Zengin, G.; Uysal, A.; Jeko, J.; Cziáky, Z.; Reis, C.P.; Gaspar, M.M.; et al. If you cannot beat them, join them: Exploring the fruits of the invasive species Carpobrotus edulis (L.) N.E. Br as a source of bioactive products. Ind. Crops Prod. 2020, 144, 112005. [CrossRef]

34. Qasim, M.; Abideen, Z.; Adnan, M.Y.; Gulzar, S.; Gul, B.; Rasheed, M.; Khan, M.A. Antioxidant properties, phenolic composition, bioactive compounds and nutritive value of medicinal halophytes commonly used as herbal teas. S. Afr. J. Bot. 2017, 110, 240-250. [CrossRef]

35. Ksouri, R.; Falleh, H.; Megdiche, W.; Trabelsi, N.; Mhamdi, B.; Chaieb, K.; Bakrouf, A.; Magné, C.; Abdelly, C. Antioxidant and antimicrobial activities of the edible medicinal halophyte Tamarix gallica L. and related polyphenolic constituents. Food Chem. Toxicol. 2009, 47, 2083-2091. [CrossRef]

36. Julkunen-Tiitto, R. Phenolic Constituents in the Leaves of Northern Willows: Methods for the Analysis of Certain Phenolics. J. Agric. Food Chem. 1985, 33, 213-217. [CrossRef]

37. Houta, O.; Neffati, M.; Amri, H. Phenolic Contents and Antioxidant Potential of Cakile maritimum. J. Biol. Act. Prod. Nat. 2012, 2, 387-391. [CrossRef]

38. Houta, O.; Akrout, A.; Amri, H. Phenolic amounts, antioxidant and antimicrobial potential of Crithmum maritimum cultivated in Tunisian arid zones. Planta Med. 2011, 77, 1416. [CrossRef]

39. Jallali, I.; Zaouali, Y.; Missaoui, I.; Smeoui, A.; Abdelly, C.; Ksouri, R. Variability of antioxidant and antibacterial effects of essential oils and acetonic extracts of two edible halophytes: Crithmum maritimum L. and Inula crithmö̈des L. Food Chem. 2014, 145, 1031-1038. [CrossRef]

40. Medini, F.; Fellah, H.; Ksouri, R.; Abdelly, C. Total phenolic, flavonoid and tannin contents and antioxidant and antimicrobial activities of organic extracts of shoots of the plant Limonium delicatulum. J. Taibah Univ. Sci. 2014, 8, 216-224. [CrossRef]

41. Karker, M.; Falleh, H.; Msaada, K.; Smaoui, A.; Abdelly, C.; Legault, J.; Ksouri, R. Antioxidant, Anti-inflammatory and anticancer activities of the medicinal halophyte Reaumuria vermiculata. EXCLI J. 2016, 15, 297-307. [CrossRef]

42. Mariem, S.; Hanen, F.; Inès, J.; Mejdi, S.; Riadh, K. Phenolic profile, biological activities and fraction analysis of the medicinal halophyte Retama raetam. S. Afr. J. Bot. 2014, 94, 114-121. [CrossRef]

43. Boulaaba, M.; Medini, F.; Hajlaoui, H.; Mkadmini, K.; Falleh, H.; Ksouri, R.; Isoda, H.; Smaoui, A.; Abdelly, C. Biological activities and phytochemical analysis of phenolic extracts from Salsola kali L. Role of endogenous factors in the selection of the best plant extracts. S. Afr. J. Bot. 2019, 123, 193-199. [CrossRef]

44. Gargouri, M.; Magné, C.; Dauvergne, X.; Ksouri, R.; El Feki, A.; Metges, M.A.G.; Talarmin, H. Cytoprotective and antioxidant effects of the edible halophyte Sarcocornia perennis L. (swampfire) against lead-induced toxicity in renal cells. Ecotoxicol. Environ. Saf. 2013, 95, 44-51. [CrossRef] [PubMed]

45. Oueslati, S.; Ksouri, R.; Falleh, H.; Pichette, A.; Abdelly, C.; Legault, J. Phenolic content, antioxidant, anti-inflammatory and anticancer activities of the edible halophyte Suaeda fruticosa Forssk. Food Chem. 2012, 132, 943-947. [CrossRef]

46. Khoddami, A.; Wilkes, M.; Roberts, T. Techniques for Analysis of Plant Phenolic Compounds. Molecules 2013, 18, 2328-2375. [CrossRef]

47. Singleton, V.L.; Rossi, J.A. Colorimetry of Total Phenolics with Phosphomolybdic-Phosphotungstic Acid Reagents. Am. J. Enol. Vitic. 1965, 16 .

48. Dewanto, V.; Xianzhong, W.; Adom, K.K.; Liu, R.H. Thermal processing enhances the nutritional value of tomatoes by increasing total antioxidant activity. J. Agric. Food Chem. 2002, 50, 3010-3014. [CrossRef] [PubMed]

49. Stanković, M.S.; Petrović, M.; Godjevac, D.; Stevanović, Z.D. Screening inland halophytes from the central balkan for their antioxidant activity in relation to total phenolic compounds and flavonoids: Are there any prospective medicinal plants? J. Arid Environ. 2015, 120, 26-32. [CrossRef]

50. Rodrigues, M.J.; Soszynski, A.; Martins, A.; Rauter, A.P.; Neng, N.R.; Nogueira, J.M.F.; Varela, J.; Barreira, L.; Custódio, L. Unravelling the antioxidant potential and the phenolic composition of different anatomical organs of the marine halophyte Limonium algarvense. Ind. Crops Prod. 2015, 77, 315-322. [CrossRef]

51. Pereira, C.G.; Barreira, L.; da Rosa Neng, N.; Nogueira, J.M.F.; Marques, C.; Santos, T.F.; Varela, J.; Custódio, L. Searching for new sources of innovative products for the food industry within halophyte aromatic plants: In vitro antioxidant activity and phenolic and mineral contents of infusions and decoctions of Crithmum maritimum L. Food Chem. Toxicol. 2017, 107, 581-589. [CrossRef]

52. Zengin, G.; Aumeeruddy-Elalfi, Z.; Mollica, A.; Yilmaz, M.A.; Mahomoodally, M.F. In vitro and in silico perspectives on biological and phytochemical profile of three halophyte species-A source of innovative phytopharmaceuticals from nature. Phytomedicine 2018, 38, 35-44. [CrossRef]

53. Mohammed, H.A.; Ali, H.M.; Qureshi, K.A.; Alsharidah, M.; Kandil, Y.I.; Said, R.; Mohammed, S.A.A.; Al-Omar, M.S.; Al Rugaie, O.; Abdellatif, A.A.H.; et al. Comparative Phytochemical Profile and Biological Activity of Four Major Medicinal Halophytes from Qassim Flora. Plants 2021, 10, 2208. [CrossRef] 
54. Do, Q.D.; Angkawijaya, A.E.; Tran-Nguyen, P.L.; Huynh, L.H.; Soetaredjo, F.E.; Ismadji, S.; Ju, Y.H. Effect of extraction solvent on total phenol content, total flavonoid content, and antioxidant activity of Limnophila aromatica. J. Food Drug Anal. 2014, 22, 296-302. [CrossRef]

55. Trabelsi, N.; Megdiche, W.; Ksouri, R.; Falleh, H.; Oueslati, S.; Soumaya, B.; Hajlaoui, H.; Abdelly, C. Solvent effects on phenolic contents and biological activities of the halophyte Limoniastrum monopetalum leaves. LWT Food Sci. Technol. 2010, 43, 632-639. [CrossRef]

56. Medini, F.; Bourgou, S.; Lalancette, K.G.; Snoussi, M.; Mkadmini, K.; Coté, I.; Abdelly, C.; Legault, J.; Ksouri, R. Phytochemical analysis, antioxidant, anti-inflammatory, and anticancer activities of the halophyte Limonium densiflorum extracts on human cell lines and murine macrophages. S. Afr. J. Bot. 2015, 99, 158-164. [CrossRef]

57. Padalino, L.; Costa, C.; Del Nobile, M.A.; Conte, A. Extract of Salicornia europaea in fresh pasta to enhance phenolic compounds and antioxidant activity. Int. J. Food Sci. Technol. 2019, 54, 3051-3057. [CrossRef]

58. Silva, A.M.; Lago, J.P.; Pinto, D.; Moreira, M.M.; Grosso, C.; Cruz Fernandes, V.; Delerue-Matos, C.; Rodrigues, F. Salicornia ramosissima Bioactive Composition and Safety: Eco-Friendly Extractions Approach (Microwave-Assisted Extraction vs. Conventional Maceration). Appl. Sci. 2021, 11, 4744. [CrossRef]

59. Saleem, H.; Khurshid, U.; Sarfraz, M.; Tousif, M.I.; Alamri, A.; Anwar, S.; Alamri, A.; Ahmad, I.; Abdallah, H.H.; Mahomoodally, F.M.; et al. A comprehensive phytochemical, biological, toxicological and molecular docking evaluation of Suaeda fruticosa (L.) Forssk.: An edible halophyte medicinal plant. Food Chem. Toxicol. 2021, 154, 112348. [CrossRef] [PubMed]

60. Saleem, H.; Zengin, G.; Locatelli, M.; Ahmad, I.; Khaliq, S.; Mahomoodally, M.F.; Hussain, R.; Rengasamy, K.R.R.; Mollica, A.; Zainal Abidin, S.A.; et al. Pharmacological, phytochemical and in-vivo toxicological perspectives of a xero-halophyte medicinal plant: Zaleya pentandra (L.) Jeffrey. Food Chem. Toxicol. 2019, 131, 110535. [CrossRef]

61. Lopes, M.; Sanches-Silva, A.; Castilho, M.; Cavaleiro, C.; Ramos, F. Halophytes as source of bioactive phenolic compounds and their potential applications. Crit. Rev. Food Sci. Nutr. 2021. [CrossRef] [PubMed]

62. Jdey, A.; Falleh, H.; Ben Jannet, S.; Mkadmini Hammi, K.; Dauvergne, X.; Ksouri, R.; Magné, C. Phytochemical investigation and antioxidant, antibacterial and anti-tyrosinase performances of six medicinal halophytes.S. Afr. J. Bot. 2017, 112, 508-514 [CrossRef]

63. Ventura, Y.; Wuddineh, W.A.; Myrzabayeva, M.; Alikulov, Z.; Khozin-Goldberg, I.; Shpigel, M.; Samocha, T.M.; Sagi, M. Effect of seawater concentration on the productivity and nutritional value of annual Salicornia and perennial Sarcocornia halophytes as leafy vegetable crops. Sci. Hortic. 2011, 128, 189-196. [CrossRef]

64. Pangestuti, R.; Kim, S.K. Biological activities and health benefit effects of natural pigments derived from marine algae. J. Funct. Foods 2011, 3, 255-266. [CrossRef]

65. Egner, P.A.; Muñoz, A.; Kensler, T.W. Chemoprevention with chlorophyllin in individuals exposed to dietary aflatoxin. Mutat. Res. Fundam. Mol. Mech. Mutagen. 2003, 523-524, 209-216. [CrossRef]

66. Viera, I.; Pérez-Gálvez, A.; Roca, M. Green natural colorants. Molecules 2019, 24. [CrossRef]

67. Duarte, B.; Santos, D.; Marques, J.C.; Caçador, I. Ecophysiological adaptations of two halophytes to salt stress: Photosynthesis, PS II photochemistry and anti-oxidant feedback - Implications for resilience in climate change. Plant Physiol. Biochem. 2013, 67, 178-188. [CrossRef] [PubMed]

68. Geissler, N.; Hussin, S.; Koyro, H.-W. Elevated atmospheric $\mathrm{CO} 2$ concentration ameliorates effects of $\mathrm{NaCl}$ salinity on photosynthesis and leaf structure of Aster tripolium L. J. Exp. Bot. 2008, 60, 137-151. [CrossRef] [PubMed]

69. Lichtenthaler, H.K.; Wellburn, A.R. Determinations of total carotenoids and chlorophylls a and b of leaf extracts in different solvents. Biochem. Soc. Trans. 1983, 11, 591-592. [CrossRef]

70. Sghaier, D.B.; Duarte, B.; Bankaji, I.; Caçador, I.; Sleimi, N. Growth, chlorophyll fluorescence and mineral nutrition in the halophyte Tamarix gallica cultivated in combined stress conditions: Arsenic and NaCl. J. Photochem. Photobiol. B Biol. 2015, 149, 204-214. [CrossRef] [PubMed]

71. Küpper, H.; Seibert, S.; Parameswaran, A. Fast, sensitive, and inexpensive alternative to analytical pigment HPLC: Quantification of chlorophylls and carotenoids in crude extracts by fitting with Gauss peak spectra. Anal. Chem. 2007, 79, 7611-7627. [CrossRef] [PubMed]

72. Mendes, C.R.; Cartaxana, P.; Brotas, V. HPLC determination of phytoplankton and microphytobenthos pigments: Comparing resolution and sensitivity of a $\mathrm{C}_{18}$ and a $\mathrm{C}_{8}$ method. Limnol. Oceanogr. Methods 2007, 5, 363-370. [CrossRef]

73. Aghaleh, M.; Niknam, V.; Ebrahimzadeh, H.; Razavi, K. Salt stress effects on growth, pigments, proteins and lipid peroxidation in Salicornia persica and S. europaea. Biol. Plant. 2009, 53, 243-248. [CrossRef]

74. Vernon, L.P. Spectrophotometry Determination of Chlorophylls and Pheophytins in Plant Extracts. Anal. Chem. 1960, 32, 1144-1150. [CrossRef]

75. Arnon, D.I. Copper Enymes in Isolated Chloroplasts. Polyphenoloxidase in Beta vulagris. Plant Physiol. 1949, 24, 1-15. [CrossRef] [PubMed]

76. Nagata, M.; Yamashita, I. Simple Method for Simultaneous Determination of Chlorophyll and Carotenoids in Tomato Fruit. Nippon Shokuhin Kogyo Gakkaishi 1992, 39, 925-928. [CrossRef]

77. Parida, A.K.; Kumari, A.; Panda, A.; Rangani, J.; Agarwal, P.K. Photosynthetic pigments, betalains, proteins, sugars, and minerals during Salicornia brachiata senescence. Biol. Plant. 2018, 62, 343-352. [CrossRef] 
78. De Souza, M.; Mendes, C.; Doncato, K.; Badiale-Furlong, E.; Costa, C. Growth, Phenolics, Photosynthetic Pigments, and Antioxidant Response of Two New Genotypes of Sea Asparagus (Salicornia neei Lag.) to Salinity under Greenhouse and Field Conditions. Agriculture 2018, 8, 115. [CrossRef]

79. Akcin, A.; Yalcin, E. Effect of salinity stress on chlorophyll, carotenoid content, and proline in Salicornia prostrata Pall. and Suaeda prostrata Pall. subsp. prostrata (Amaranthaceae). Rev. Bras. Bot. 2016, 39, 101-106. [CrossRef]

80. Bernal, J.; Mendiola, J.A.; Ibáñez, E.; Cifuentes, A. Advanced analysis of nutraceuticals. J. Pharm. Biomed. Anal. 2011, 55, 758-774. [CrossRef]

81. Duxbury, A.C.; Yentsch, C.S. Plankton Pigment Nomographs. J. Mar. Res. 1956, 15, 92-101.

82. Ben-Amotz, A.; Lers, A.; Avron, M. Stereoisomers of $\beta$-Carotene and Phytoene in the Alga Dunaliella bardawil. Plant Physiol. 1988, 86, 1286-1291. [CrossRef]

83. Uslu, L.; Durmaz, Y.; Duyar, H.A.; Bandarra, N.M. Fatty acids, $\alpha$-tocopherol and proximate composition of four red macroalgae in the Sinop Bay (Turkey). J. Anim. Vet. Adv. 2013, 12, 29-33. [CrossRef]

84. Kumari, A.; Parida, A.K.; Rangani, J.; Panda, A. Antioxidant Activities, Metabolic Profiling, Proximate Analysis, Mineral Nutrient Composition of Salvadora persica Fruit Unravel a Potential Functional Food and a Natural Source of Pharmaceuticals. Front. Pharmacol. 2017, 8, 61. [CrossRef] [PubMed]

85. Rangani, J.; Kumari, A.; Patel, M.; Brahmbhatt, H.; Parida, A.K. Phytochemical profiling, polyphenol composition, and antioxidant activity of the leaf extract from the medicinal halophyte Thespesia populnea reveal a potential source of bioactive compounds and nutraceuticals. J. Food Biochem. 2019, 43, e12731. [CrossRef] [PubMed]

86. Chamovitz, D.; Sandmann, G.; Hirschberg, J. Molecular and biochemical characterization of herbicide-resistant mutants of cyanobacteria reveals that phytoene desaturation is a rate-limiting step in carotenoid biosynthesis. J. Biol. Chem. 1993, 268, 17348-17353. [CrossRef]

87. Vitamin and Mineral Requirements in Human Nutrition_World Health Organization, FAO_ Google Books. Available online: https:/ / books.google.dk/books?hl=en\&lr=\&id=NjdkYRkHla0C\&oi=fnd\&pg=PR1\&dq=vitamin+source+human+nutrition\& ots=I9UYVSFFzB\&sig=BFJ4bRMC2iIqlkmb8wenIOQRQks\&redir_esc=y\#v=onepage \&q=vitaminsourcehumannutrition $\& \mathrm{f}=$ false (accessed on 18 August 2021).

88. Santos, J.; Mendiola, J.A.; Oliveira, M.B.P.P.; Ibáñez, E.; Herrero, M. Sequential determination of fat- and water-soluble vitamins in green leafy vegetables during storage. J. Chromatogr. A 2012, 1261, 179-188. [CrossRef]

89. Chamkouri, N.; Khodadoust, S.; Ghalavandi, F. Solid-Phase Extraction Coupled with HPLC-DAD for Determination of B Vitamin Concentrations in Halophytes. J. Chromatogr. Sci. 2015, 53, bmv080. [CrossRef] [PubMed]

90. Maatallah Zaier, M.; Ciudad-Mulero, M.; Cámara, M.; Pereira, C.; Ferreira, I.C.F.R.; Achour, L.; Kacem, A.; Morales, P. Revalorization of Tunisian wild Amaranthaceae halophytes: Nutritional composition variation at two different phenotypes stages. J. Food Compos. Anal. 2020, 89, 103463. [CrossRef]

91. Berretta, M.; Quagliariello, V.; Maurea, N.; Di Francia, R.; Sharifi, S.; Facchini, G.; Rinaldi, L.; Piezzo, M.; Ceccarelli, M.; Nunnari, G.; et al. Multiple effects of ascorbic acid against chronic diseases: Updated evidence from preclinical and clinical studies. Antioxidants 2020, 9, 1-27. [CrossRef] [PubMed]

92. Nakos, M.; Pepelanova, I.; Beutel, S.; Krings, U.; Berger, R.G.; Scheper, T. Isolation and analysis of vitamin B12 from plant samples. Food Chem. 2017, 216, 301-308. [CrossRef] [PubMed]

93. Ellouzi, H.; Ben Hamed, K.; Cela, J.; Munné-Bosch, S.; Abdelly, C. Early effects of salt stress on the physiological and oxidative status of Cakile maritima (halophyte) and Arabidopsis thaliana (glycophyte). Physiol. Plant. 2011, 142, 128-143. [CrossRef] [PubMed]

94. Hachicha, S.F.; Barrek, S.; Skanji, T.; Zarrouk, H.; Ghrabi, Z.G. Fatty acid, tocopherol, and sterol content of three Teucrium species from Tunisia. Chem. Nat. Compd. 2009, 45, 304-308. [CrossRef]

95. Rodriguez-Amaya, D.B. Provitamin A activity. In Food Carotenoids; John Wiley \& Sons, Ltd.: Chichester, UK, 2015 ; pp. $255-281$.

96. Karan, S.; Turan, C.; Sangun, M.K. Use of Glasswort (Saliconia Europaea) Plant as Raw Material in Cosmetics. In Proceedings of the 2nd International Cosmetic Congress "Green Comsetics", Antalya, Turkey, 28-30 October 2018.

97. Sung, J.H.; Park, S.H.; Seo, D.H.; Lee, J.H.; Hong, S.W.; Hong, S.S. Antioxidative and skin-whitening effect of an aqueous extract of salicornia herbacea. Biosci. Biotechnol. Biochem. 2009, 73, 552-556. [CrossRef] [PubMed]

98. Guillerme, J.B.; Couteau, C.; Coiffard, L. Applications for marine resources in cosmetics. Cosmetics 2017, 4, 35. [CrossRef]

99. Ferreira, M.S.; Magalhães, M.C.; Oliveira, R.; Sousa-Lobo, J.M.; Almeida, I.F. Trends in the Use of Botanicals in Anti-Aging Cosmetics. Molecules 2021, 26, 3584. [CrossRef] [PubMed]

100. Brusotti, G.; Cesari, I.; Dentamaro, A.; Caccialanza, G.; Massolini, G. Isolation and characterization of bioactive compounds from plant resources: The role of analysis in the ethnopharmacological approach. J. Pharm. Biomed. Anal. 2014, 87, 218-228. [CrossRef]

101. Patra, J.K.; Das, G.; Lee, S.; Kang, S.S.; Shin, H.S. Selected commercial plants: A review of extraction and isolation of bioactive compounds and their pharmacological market value. Trends Food Sci. Technol. 2018, 82, 89-109. [CrossRef]

102. Doughari, J.H. Phytochemicals: Extraction Methods, Basic Structures and Mode of Action as Potential Chemotherapeutic Agents. In Phytochemicals - A Global Perspective of Their Role in Nutrition and Health; Rao, D.V., Ed.; IntechOpen: London, UK, 2012; ISBN 978-953-51-0296-0. 
103. Essaidi, I.; Brahmi, Z.; Snoussi, A.; Ben Haj Koubaier, H.; Casabianca, H.; Abe, N.; El Omri, A.; Chaabouni, M.M.; Bouzouita, N. Phytochemical investigation of Tunisian Salicornia herbacea L., antioxidant, antimicrobial and cytochrome P450 (CYPs) inhibitory activities of its methanol extract. Food Control 2013, 32, 125-133. [CrossRef]

104. Meot-Duros, L.; Cérantola, S.; Talarmin, H.; Le Meur, C.; Le Floch, G.; Magné, C. New antibacterial and cytotoxic activities of falcarindiol isolated in Crithmum maritimum L. leaf extract. Food Chem. Toxicol. 2010, 48, 553-557. [CrossRef] 